\title{
Work by Anthony P. Yim, MD-A Surgeon-turned-Artist
}

\author{
Anthony P. Yim \\ Founder, Art from Heart Project, Hong Kong, China \\ Correspondence to: Anthony P. Yim, MD. Founder, Art from Heart Project, Hong Kong, China. Email: yimap@yahoo.com.hk.
}

Submitted Aug 11, 2020. Accepted for publication Aug 30, 2020.

doi: $10.21037 /$ cdt-20-721

View this article at: http://dx.doi.org/10.21037/cdt-20-721

\section{Introduction of the artist}

Compared to most artists, Dr. Anthony P. Yim came from a very unusual background. He studied medicine and graduated with double first class honours from Cambridge University in 1981 followed by clinical education at Oxford University, and residency training in the States. He returned to join the Chinese University of Hong Kong in 1992, and pioneered the development of Minimally Invasive Thoracic Surgery which earned him an international reputation as a top surgeon-scientist and teacher. This keyhole approach set a new standard for chest surgery, and has since benefited hundreds of thousands of patients worldwide. He was the recipient of many Visiting Professorships, named Lecturerships around the world, as well as editorial board memberships of some of the most premier medical journals

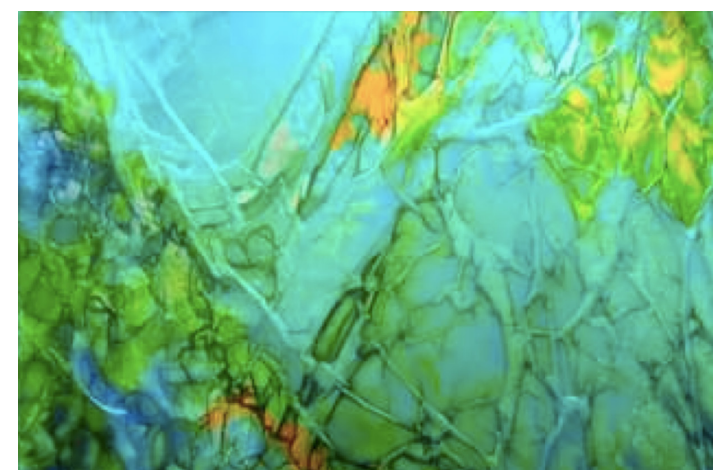

Figure 1 Aspiration (2020) $(50 \mathrm{~cm} \times 50 \mathrm{~cm})$. Ink on Paper (courtesy of the Ink House, Hong Kong SAR, China). Source: https:// m.facebook.com/story.php?story_fbid=2608549319460542\& id $=100009164996201$ in his field. He was awarded Doctor of Medicine by the University of Oxford in 1999, and named a Chair Professor of Surgery at the Chinese University of Hong Kong in 2002. He formally retired from surgery in 2017 to pursue his childhood dream of becoming an artist.

His book, My Second Career, published by AME in 2018 contains more than 200 pieces of artwork by Dr. Yim in four categories, namely porcelain, watercolor, acrylic, and Chinese paintings. Collectively, they documented not only his personal achievement in the pursuit of art, but also the sharp transaction from a surgeon into an artist. His journey should provide some insight for those who have an interest in art and are considering taking this up more seriously. More details are available in this online art gallery: https:// gallery.amegroups.com/.

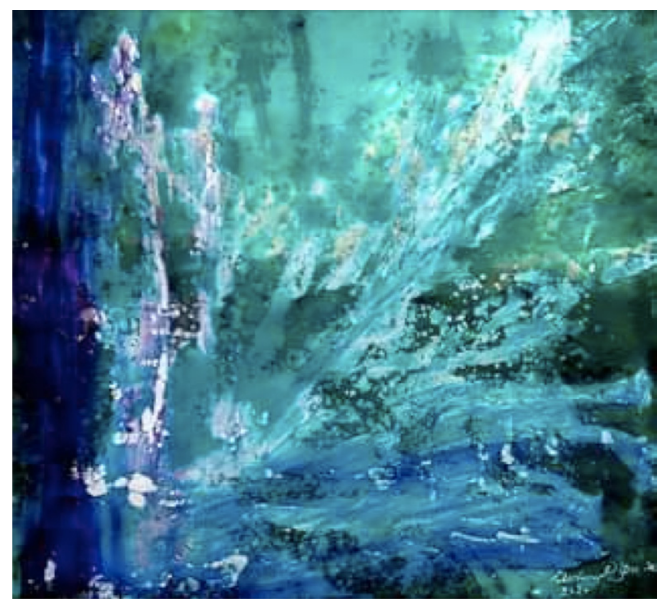

Figure 2 Tidal Waves $(2020)(54 \mathrm{~cm} \times 54 \mathrm{~cm})$. Ink on silver card (courtesy of the Ink House, Hong Kong SAR, China). Source: https://m.facebook.com/story.php?story_fbid=2590755091239965 \&id=100009164996201 


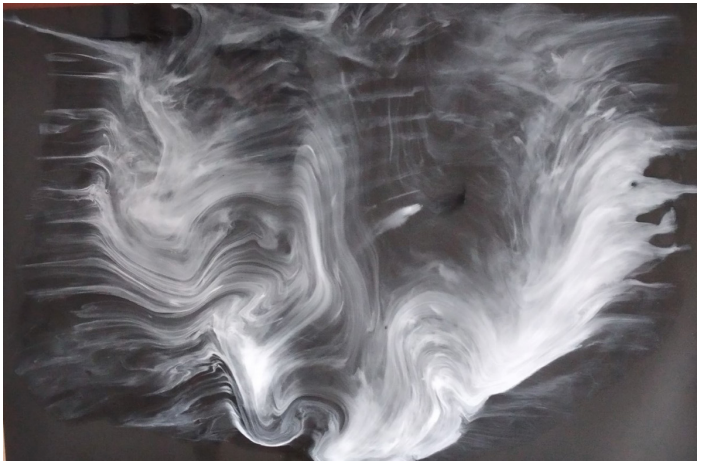

Figure 3 Abstract or reality; 2D or 3D; Does it matter? (2020) (53 $\mathrm{cm} \times 75 \mathrm{~cm})$. Acrylic and white ink on black card. Source: https:// m.facebook.com/story.php? story_fbid=2701350376847102\& id $=100009164996201$

More of Dr. Yim's most recent work (Figures 1-4) can be seen at: https://m.facebook.com/profile.php?id=100009164 996201\&fref=nf\&ref=wizard.

\section{Acknowledgments}

Funding: None.

\section{Footnote}

Provenance and Peer Review: This article was commissioned by the editorial office, Cardiovascular Diagnosis and Therapy for the series "Arts and Medicine". This article did not undergo external peer review.

Conflicts of Interest: The author has completed the ICMJE uniform disclosure form (available at http://dx.doi. org/10.21037/cdt-20-721). The series "Arts and Medicine" was commissioned by the editorial office, Cardiovascular

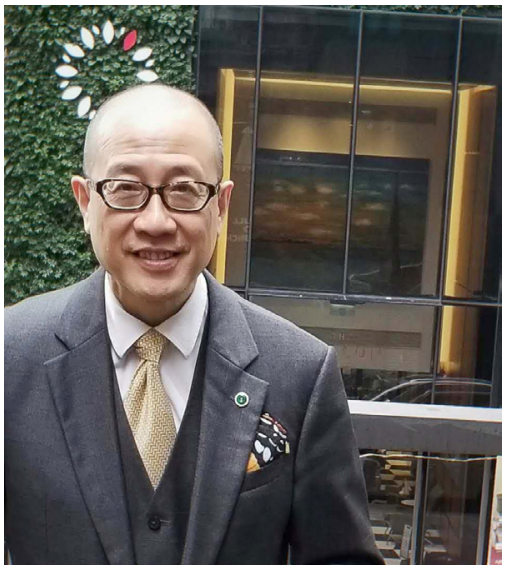

Figure 4 Anthony P Yim, MD. In the backdrop across the street is his huge painting, the Guiding Light, at the Beacon. https:// m.facebook.com/story.php?story_fbid=2095987920716687\& id=100009164996201

Diagnosis and Therapy without any sponsorship or funding. The author has no conflicts of interest to declare.

Ethical Statement: The author is accountable for all aspects of the work in ensuring that questions related to the accuracy or integrity of any part of the work are appropriately investigated and resolved.

Open Access Statement: This is an Open Access article distributed in accordance with the Creative Commons Attribution-NonCommercial-NoDerivs 4.0 International License (CC BY-NC-ND 4.0), which permits the noncommercial replication and distribution of the article with the strict proviso that no changes or edits are made and the original work is properly cited (including links to both the formal publication through the relevant DOI and the license). See: https://creativecommons.org/licenses/by-nc-nd/4.0/.
Cite this article as: Yim AP. Work by Anthony P. Yim, MD-A Surgeon-turned-Artist. Cardiovasc Diagn Ther 2020;10(5):1768-1769. doi: 10.21037/cdt-20-721 